reports a new mechanism of resistance to crizotinib in one patient, showing that the search for effective targeted treatments must continue.

N. Engl. J. Med. 368, 2385-2394; 368, 2395-2401 (2013)

\section{PALAEONTOLOGY}

\section{Ancient 'starfish'} had a helix

Five rays twisting down from the top of a fossil hint at how creatures such as starfish gained their unusual symmetry.

Starfish, sea urchins and all other known living echinoderms have a symmetry that allows them to be sliced into five identical parts, but some of their counterparts in the Cambrian period, which began about

540 million years ago, were asymmetric or had bilateral symmetry.

Andrew Smith at the Natural History Museum in London and Samuel Zamora at the Smithsonian Institution in Washington DC discovered Cambrian fossils in Morocco that show what stages intermediate to the body plan of living echinoderms might have looked like.

Helicocystis moroccoensis (pictured) is the oldest known echinoderm with fivepart symmetry; it resembled an egg with its tapered end planted in the sea floor. Its mouth opened upward and its body spiralled down.

Proc. R. Soc. B 280, 20131197 (2013)

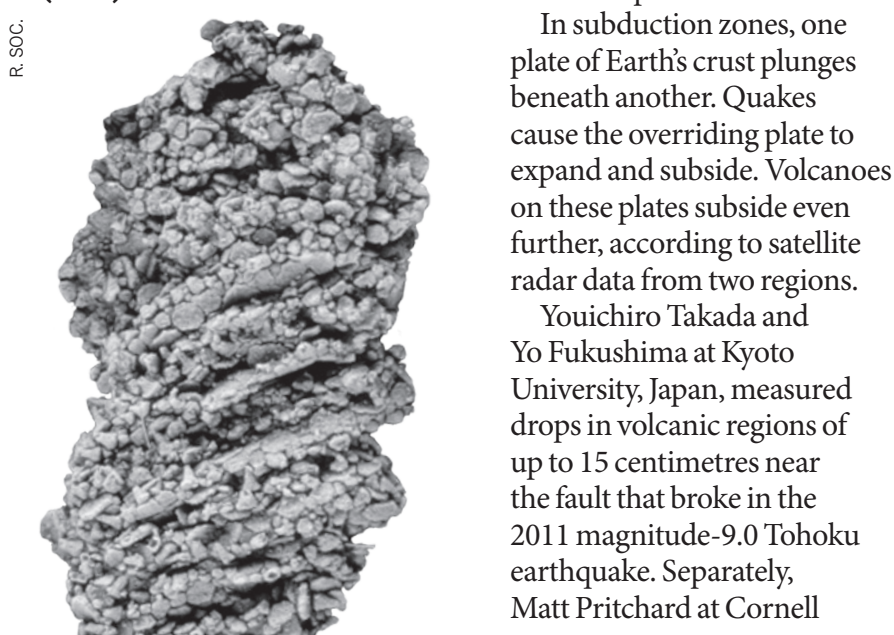

\section{Hot sex for jawless fish}

After dancing seductively for their potential mates, male sea lampreys (Petromyzon marinus) crank up the heat, literally, using a ridge of tissue on their backs.

Courtship behaviour of lampreys - eel-like, bloodsucking, jawless fishes — includes the male rubbing his ridge against the belly of an interested female. Researchers had assumed that this simply aroused females mechanically, but when Weiming Li and his colleagues at Michigan State University in East Lansing dissected the tissue, they found that ridges from mature males were full of cells packed with oil droplets and cells primed for energy production, a hallmark of heat-producing tissue. The ridge temperature in males jumped by up to $0.3^{\circ} \mathrm{C}$ in the presence of sexually mature females.

The authors say that the ridge is the first example of a heat-generating sexual trait. J. Exp. Biol. 216, 2702-2712 (2013)

\section{GEOSCIENCE}

\section{Earthquakes sink volcanoes}

Giant earthquakes in subduction zones do not just create tsunamis - they can also cause nearby volcanic regions to sink, possibly altering the risk of eruptions.

In subduction zones, one plate of Earth's crust plunges beneath another. Quakes cause the overriding plate to expand and subside. Volcanoes on these plates subside even further, according to satellite radar data from two regions.

Youichiro Takada and

Yo Fukushima at Kyoto University, Japan, measured 2011 magnitude-9.0 Tohoku Matt Pritchard at Cornell

COMMUNITY CHOICE

The most viewed papers in science

\title{
Super-broccoli secret solved
}

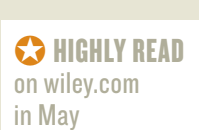

A single gene is probably responsible for high levels of sulphur-containing compounds in new commercial varieties of broccoli.

Richard Mithen at the Institute of Food Research in Norwich, UK, and his group analysed hundreds of genetic markers in broccoli hybrids (pictured) bred to produce more glucoraphanin, a compound with reported health benefits. The team had previously created the three hybrid lines by crossing common broccoli (Brassica oleracea) and a wild Sicilian cousin (Brassica villosa) multiple times. The analysis showed that the hybrids had all inherited a version of a gene from $B$. villosa. The gene, called $M y b 28$, also regulates glucoraphanin production in the model plant Arabidopsis. Field trials under diverse conditions showed that the hybrids consistently had higher levels of the compound. The plants both drew more sulphur-containing building blocks from the soil and shunted a greater portion of them towards glucoraphanin production. The work paves the way for blinded human studies that assess the health benefits of eating the glucoraphanin-rich broccoli, the authors say.

New Phytol. 198, 1085-1095 (2013)

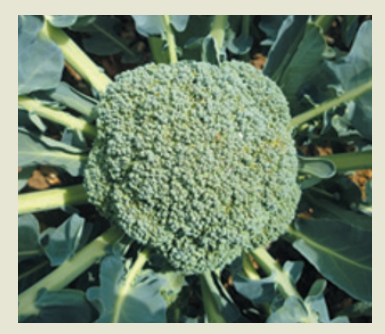

University in Ithaca, New

York, and his colleagues

measured subsidence of up to 15 centimetres within weeks of the 2010 magnitude- 8.8 Maule earthquake off the coast of Chile.

The authors of the Japanese study suggest that the subsidence occurred because reservoirs of magma below the volcanoes sank. By contrast, the authors of the Chilean study say that hydrothermal reservoirs may have drained, causing the ground above to collapse. Nature Geosci. http://dx.doi. org/10.1038/ngeo1857; http:// dx.doi.org/10.1038/ngeo1855 (2013)

\section{Clock blocked by age}

A protein linked to ageing and metabolic disease might control the brain's internal clock.
The protein SIRT1 regulates the expression of many genes and has been linked to daily biological cycles called circadian rhythms in tissues such as fat and the liver. HungChun Chang and Leonard Guarente at the Massachusetts Institute of Technology in Cambridge found that in mouse brains, SIRT1 switches on two proteins that are known to regulate circadian rhythms.

Aged mice were slower than young mice to adjust to shifts in light-dark cycles, and expressed lower levels of SIRT1 in the brain region that sets circadian rhythms. Boosting SIRT1 levels shortened animals' adjustment time, whereas depleting SIRT1 lengthened it.

Cell 153, 1448-1460 (2013)

\section{$\rightarrow$ NATURE.COM}

For the latest research published by Naturevisit:

www.nature.com/latestresearch 